\title{
Anaerobic degradation of hydroaromatic compounds by newly isolated fermenting bacteria
}

\author{
Andreas Brune* and Bernhard Sehink** \\ Lchrstuhl Mikrobiologit I, Universilät Tübingen, Auf der Morgenstelle 28, W-7400 Tübingen, Federal Republic of Germany
}

Received February 27, 1992/Accepted June 2, 1992

\begin{abstract}
Aerobic organisms degrade bydroaromatic compounds via the hydroaromatic pathway yielding protocatechuic acid which is [urther metabolized by oxygenase-mediated ring fission in the 3-oxoadipate pathway. No information exists on anaerobic degradation of hydroaromatics so far. We enriched and isolated from various sources of anoxic sediments several strains of rapidly growing gram-negative bacteria fermenting quinic (1,3,4,5-tetrahydroxy-cyclohexane-1-carboxylic acid) and shikimic acid $(3,4,5$-trihydroxy-1-cyclohexene1-carboxylic acid) in the absence of external electron acceptors. Quinic and shikimic acid were the only ones utilized of more than 30 substrates tested. The marine isolates formed acctate, butyrate, and $\mathrm{H}_{2}$, whereas all freshwater strains formed acetate and propionate as typical fermentation products. Aromatic intermediates were not involved in this degradation. Characterization of the isolates, fermentation balances for both hydroaromatic compounds, and enzyme activities involved in one degradation pathway are presented.
\end{abstract}

Key words: Anaerobic degradation - Hydroaromatic compounds - Quinic acid - Shikimic acid

Quinic (1) and shikimic (2) acid are important precursors in the biosynthesis of aromatic compounds (Fig. 1) (Minamikawa 1976; Herbert 1981). In vascular plants, these hydroaromatic carboxylates are stored in con-

\footnotetext{
* Present address: Department of Microbiology and Public Health, Michigan State Universily, Fast Lansing, MI 48824-1101, USA

* Corresponaing author and present address: Fakultät für Biologie, Lniversität Konstanz. Postfach 5560, W-7750 Konstanz, FRG

Abbreviations: $\mathrm{BV}$, bencyl viologen $\left(1,1^{\prime}\right.$-dibenzyl-4,4'-bipy ridinium dichloride); $C O A$, coenzyme $A ; C l \wedge B$, cetyltrimethylammonium bromide; DCPIP, 2.4-dichlorophenolindophenol; D'I'T, 1.4-dithiothreitol; MV, methyl viologen, (1,1'-dimethyl-4,4'bipyridinium dichloride); Tricine, $N$-[tris-(hydroxymethyl)-methyl]-glycine; Tris, tris-(hydroxymethyl) aminomethane
}<smiles>O=C(O)C1(O)CC(O)C(O)C(O)C1</smiles><smiles>O=C(O)C1=CC(O)C(O)C(O)C1</smiles><smiles>O=C(O)c1ccc(O)c(O)c1</smiles>

Fig. 1. Structurai formulas of quinic ( () , shikimic (2), and protocatechu1c (3) acid

siderable amounts as building blocks for synthesis of lignin and phenols (Boudet 1973). Especially gymnosperms and woody dicotyledons contain these compounds at high concentrations (on average $2.21 \mathrm{mg}$ quinic and $0.16 \mathrm{mg}$ shikimic acid per $\mathrm{g}$ fresh weight; Yoshida ot a1. 1975). Quinic acid is also widespread as component of many tamins, esterified with various aromatic acids (e.g. Stoeckigt and Zenk 1974; Möller and Hermann 1983: Nishimura et al. 1984).

Oxidative degradation of hydroaromatic compounds by acrobic bacteria and fungi takes the hydroaromatic pathway and yields protocatechuic acid (3) requiring oxygenase-mediated ring fission in the 3-oxoadipate pathway. This pathway has been studied intensively with Acinetobacter (Ingledew et al. 1971), Pseudomonas (Ingledew and Tai 1972), and several fungi; with Neurospora crassa (Geever et al. 1989) and Aspergillus nidulans (Beri et al. 1990), also the regulation of this pathway was studied in detail. A hydroaromatic pathway was postulated to occur also in Rhizobiaceae (Parke and Ornston 1984) and streptomycetes (Grund et al. 1990), and was recently demonstrated in the nocardioform actinomycete, Rhodococcus rhodochrous (Bruce and Cain 1990).

Little is known about the fate of hydroaromatics in the absence of oxygen. Reduction of the hydroaromatic ring in the presence of suitable electron donors has been studied with lactobacilli (Whiting and Coggins 1971; 1974) and occurs also in the mammalian digestive tracts (Brewster et al. 1978; Wheeler et al. 1979; Martin 1982), but no report exists on degradation of the hydroaromatic ring in anoxic environments.

In this study, we enriched, isolated and characterized several strains of anaerobic, fermenting bacteria from 
various anoxic marine and freshwaler sediments. These strains degrade hydroaromatics through novel pathways not involving aromatic intermediates.

\section{Materials and methods}

\section{Media and cuttivation techniques}

All strains were isolated and routinely cultivated using the anoxic, bicarbonate-buffered. sulfide-reduced mineral medium of Widdel and Pfennig (1984), with modifications and additions described previously (Schnell et al. 1991). For saltwater enrichments, tho modium was supplemented with $\mathrm{NaCl}(20 \mathrm{~g} / 1)$ and $\mathrm{MgCl}_{2} \cdot 6 \mathrm{H}_{2} \mathrm{O}$ $(3 \mathrm{~g} / 1)$. Hydroaromatic and aromatic substrates were added from filter-sterilized, neutralized stack solutions kept under $\mathrm{N}_{2}$; other substrates were autoclaved or filter-sterilized. $5 \%$ inoculum was used routinely. Stock cultures were grown on quinic acid in completely filled 50 - $\mathrm{ml} \mathrm{screw-cap} \mathrm{bottles} \mathrm{at} 30^{\circ} \mathrm{C}$ in the dark, stored at $4{ }^{\circ} \mathrm{C}$, and had to be transferred twice monthly.

\section{Enrichment and isolation}

Enrichment cultures with quinic acid ( $5 \mathrm{mM}$ ) were inoculated with anoxic sediments from various origins: (1) organic-rich marine black mud from the canals of Venice. Italy, freshwater sediment from (2) a eutrophic pond and (3) a mildly polluted creek ncar Tübingen, FRG, and (4) anaerobic sludge from a digester of the Tübingen municipal sewage treatment plant. Pure cultures were obtained by repeated application of the agar-shake dilution technique (Widdel and Pfennig 1984). Purity was checked microscopically and by grow th tests in complex medium (AC medium, Difco, Detroil, Mich., USA), with or without added quinic acid $(5 \mathrm{mM})$.

\section{Morphological and cytological characterization}

Grara staining (Bartholomew 1962). KOHI test (Gregersen 1978), and flagella staining (Blenden and Goldberg 1965 ) were performed using standard techniques. Endospore formation was tested in a special sporulation medium (Matthies et aI. 1989).

Oxidase and catalase tests followed standard procedures (Smibert and Krieg 1981). Superoxide dismutase was assayed according to Elstner et al. (1985). The presence of cytochromes was tested by redox differcnce spcctroscopy of air-oxidized minus dithionitereduced cell exlracts (25 mg protein $\cdot \mathrm{ml}^{-1}$ ).

DNA was isolated after Cashion et al. (1977), and the guanuneplus-cytosine content of the DNA was determined directly by high-pressure liquid chromatography (Mesbah et al. 1989; Tamaoka and Komagata 1984), using phage Lambda DNA as a reference.

Wet mounts for microphotography (Pfennıg and Wagencr 1986 ) and electron mucrographs of ulfra-thin scetions (Mathies at al. 1989) were prepared as described.

\section{Physiological characterization}

Substrate utilization tests and growth experiments were performed In $25-\mathrm{ml}$ tubes with butyl rubber septa, filled with $10 \mathrm{ml}$ of sulfice-reduced medium, and gassed with $\mathrm{N}_{2} / \mathrm{CO}_{2}(9: 1)$. For determination of $\mathrm{pH}$ optima, the medium was supplemented with 2-morpholinoethane sulfonic acid (MES) and $N$-|tris-(hydroxymethy5)-methyl]-glycinc (TRICINE), $30 \mathrm{mM}$ each, and adjusted to various $\mathrm{pH}$ values with $\mathrm{NaOH}$. Turbidity was measured at $578 \mathrm{~nm}$ directly in the culture or in 1 -cm cuvettes. Growth yields with quinic acid were defermined gravimetrically in $1-1$ batch cultures (Widdel and Pfennig 1981).

Acrobic growth on hydroaromatic compounds was lested in test tubes with homogenously moculated agar medium, and in Er- lenmeyer llasks with liquid medium. incubated statically or on a rotary shaker (150 rpm). The phosphate-buffered mineral medium described by Platen and Schink (1989) was used.

\section{Enzyme assays}

Enzyme activities were determmed at $25^{\circ} \mathrm{C}$, either by spectrophotometrical (Brune and Schink 1990b) or discontinuous HPLC assays (Brunc and Schink 1990a) using freshly prepared FrenchPress extracts of quinate-grown cells. All tests were performed under $\mathrm{N}_{2}$ unless indicated otherwise.

Qumate dehydrogenase (= catabolic shikimate dehydrogenase, $\mathrm{EC} 1.1 .1 .24$ ) was measured following $\mathrm{N} \wedge \mathrm{D}^{+}$reduction $b y$ the respective hydroaromatic substrate (Bruce and Cain 1990).

Shikimate: NADP 3-oxidoreductase = anabohe shikimate dehydrogenase, EC 1.1.1.25) was measured analogously with $\mathrm{NADP}^{+}$; NAD (P) ${ }^{+}$-independent ("dye-linked") activities with DCPIP as electron acceptor (Cánovas et al. 1968).

Pyrwate synthase (LC 1.2.99.2) and 2-axobutyrate synthase (EC 1.2.7.2.) were neasured using the 2-oxoglutarate synthase assay previously described in detail (Brune and Schntk 1990b), with BV as artificial clectron acceptor, and substituting either pyruvate or 2-oxobutyrate $(10 \mathrm{mM}$ each) for 2-oxoglutarate

Proptonyl-CoA: acetate CoA transferase (EC 2.8.3.1.) and butyry-CoA: acefate CoA iranserase (EC 2.8.3.-) were determined by discontinuous HPLC analysis of the assay mixure conlaining Tris-HCl buffer $(100 \mathrm{mM}, \mathrm{pH} 7.3)$, acetyl-CoA $(0.5 \mathrm{mM})$, and the respective carboxylic acid $(10 \mathrm{mM})$.

3-Hydroxybutyryi-CoA dehydratase ( $\mathrm{HC} 4.2 .1 .55$ ) was measured analogously, following crotonyl-CoA $(0.5 \mathrm{mM})$ conversion to 3hydroxybutyryl-CoA or by a spectrophotometric assay (Platen et al. 1990)

Butyry-CoA delydrogenase (EC 1.3.99.2) was assayed spectrophotometrically at $365 \mathrm{~nm}$. The assay mixture contained K-phosphate buffer (100 mM, pH 7.0), NADH $(0.3 \mathrm{mM})$, and crotonyl$\operatorname{CoA}(1 \mathrm{mM})$.

3-Hydraxybutyry-CoA dehydrogenase (EC 1.1.1.35), acetoacetr7-CoA thiolase (EC 2.3.1.9), phosphotransacetylase (EC 2.3.1.8) and acetate kinase (EC 2.7.2.1) were measured as described (Brune and Schink 1991).

Carbon monoxide dehydrogenase (EC 1.2.99.2) was defer mined following rectuction of $\mathrm{BV}$ upon addition of carbon monoxide to the prereduced assay mixture (Diekert and Thaucr 1978). Hydrogenase (EC 1.18.99.1) was measured analogously.

Protocatechuate 3,4-dioxygenase (EC 1.13.1.3.) and catechol 1,2-dioxygenase (EC 1.13 1.1) were assayed spectrophotometrically (Staner and Ingraham 19.54; Hayaishi et al. 1957).

\section{Anatytical methods}

Acetate, propionate, and butyrate were assayed by gas chromatography with flame-ionization delection (Platen and Schink 1987). hydrogen by gas chromatography with thermal conductivity detection (Mathies et al. 1989). Coenzyme A esters were andyzed by HPLC on a reversed phase system (Brune and Schink 1991). Nitrite formation was assayed after Procházková (1959), sullide formation half-quantitatively with the assay of Cord-Ruwisch (1985). Protein was quantitated using the micro-protein assay of Bradford (1976) with bovine serum albumin as standard.

\section{Chemicals}

13(-)-Quinic acid (1R, 3R, 4S, 5R)-1.3,4,5-tetrahydroxy-cyclohexane-1-carboxylic acid) was obtained in purum quality (>98\%) from Aldrich, Steinheim, FRG; D(-)-shikimic acid [ $3 \mathrm{R}, 4 \mathrm{~S}, 5 \mathrm{R})-3,4,5-$ trihydroxy-1-cyclohexene-1-carboxylic acid] in $>97 \%$ quality was from Fluka, Neu-Ulm, FRG; both were used without further purification. Commercial sources of all other chemicals (analytical grade or highest available purity) and gases were as previously published (Brutre an Schink 1990b). 


\section{Results}

\section{Enrichment cultures}

All enrichments with quinic acid showed turbidity and gas production after incubation for $2-3$ days. Subcultures transferred to fresh medium grew within less than 1 day. After several transfers, uniform bacterial populations had developed. The respective dominating morphotypes were isolated by repeated agar-dilution series, and retransferred into liquid medium.

All marine isolates were non-motile coccoid rods or cocci, and grew rapidly with quinic acid (doubling time $1.5-2 \mathrm{~h}$ ), forming acetate, butyrate, and hydrogen as fermentation products. The freshwater isolates were motile, rod-shaped bacteria of various sizes, growing slightly slower than the saltwater strains (doubling time $\sim 2.5 \mathrm{~h}$ ), and forming only acetate and propionate as fermentation products; no hydrogen was delected. All strains formed large, lens-shaped, cream-coloured colonies in the agar medium. The strains VenChi2 (marine inoculum 1) and GolChi1 (freshwater inoculum 2) were selected for further characterization.

Enumeration of quinate-degrading bacteria in the original samples by serial dilution in anoxic liquid medium revealed very low numbers $\left(10^{2} \quad 10^{3}\right.$ cells per $\mathrm{ml}$ ) of quinate degraders in the inoculum sediment material.

\section{Morphological and cytological characterization}

Figure 2 shows phase contrast photomicrographs of strains Venchi2 and GolChil. Cells of strain VenChi2 were non-motile, coccoid rods $(0.8-1.0 \times 1.0-1.5 \mu \mathrm{m})$. Strain GolChil formed more slender, short rods (0.6 to $0.7 \times 1.5-2.5 \mu \mathrm{m}$ ) propelled rapidly by a polar flagellum (Fig. 2C). Electron micrographs of ultra-thin sections showed a typical gram-negative cell wall structure with both strains (not shown), confirming the results of Gram staining and $\mathrm{KOH}$ test. Spore formation was never observed, neither in defined media nor in special sporulation media. Strains VenChi2 and GolChil had rather different DNA base ratios. Results of the microbiologicaI characterization are summarized in Table 1.
Table 1. Microbiological characterization of strains venchi2 and GrolChil

\begin{tabular}{|c|c|c|}
\hline strain: & VenChi2 & GolChil \\
\hline Gram-type & Negative & Negative \\
\hline $\mathrm{DN} \Lambda \mathrm{G}+\mathrm{C}$ ratio $\left(\mathrm{mol}^{1} \%\right)$ & $35.7 \pm 0.1$ & $61.6+0.2$ \\
\hline Motility & - & + \\
\hline Flagellation & & $\begin{array}{l}\text { Polar monotri- } \\
\text { chous }\end{array}$ \\
\hline Growth under air & - & + \\
\hline Oxidase: & - & - \\
\hline Catalase & - & - \\
\hline Superoxide dismutase & - & + \\
\hline Cytochromes & - & $\ldots$ \\
\hline pH Optimum & $6.5-80$ & $7.0-7.5$ \\
\hline pH Limits & $6.0 / 9.0$ & $6.0 / 8.0$ \\
\hline Temp. optimum ${ }^{\mathrm{a}}\left({ }^{\circ} \mathrm{C}\right)$ & 30 & 37 \\
\hline
\end{tabular}

a not growth at $45^{\circ} \mathrm{C}$

\section{Physiological characterization}

Strain GolChil grew only in freshwater media, while strain VenChi2 grew well in saltwather and also in brackish media containing at lcast $7 \mathrm{~g} \mathrm{NaCl}$ and $0.7 \mathrm{~g}$ $\mathrm{MgCl}_{2}$ per 1. No unusual features with respect to $\mathrm{pH}$ and temperature optimum were detected (Table 1). Both strains tolerated phosphate buffer $(50 \mathrm{mM})$ without a decrease in growth yield. Thoy did not require a reductant for growth, and could be cultivated in non-reduced mineral media. However, in agar-dcep suspension under air, strain VenChi2 did not grow directly at the agar surface; a $10-\mathrm{mm}$ deep clear zone developed. Strain GolChil differed significantly with respect to oxygen sensitivity, growing homogenously throughout the agar suspension and, if not agitated, even in an Erlenmeyer flask under air. Supcroxide dismutase test was positive only with GolChil.

No substrates other than quinic or shikimic acid supported growth. No external electron acceptors were reduced, neither with propionate, lactate, nor quinate as clectron donors. Table 2 lists the substrates which did not support growth.

No additional growth factors were required by either strain for growth in the vitamin-supplemented medium.
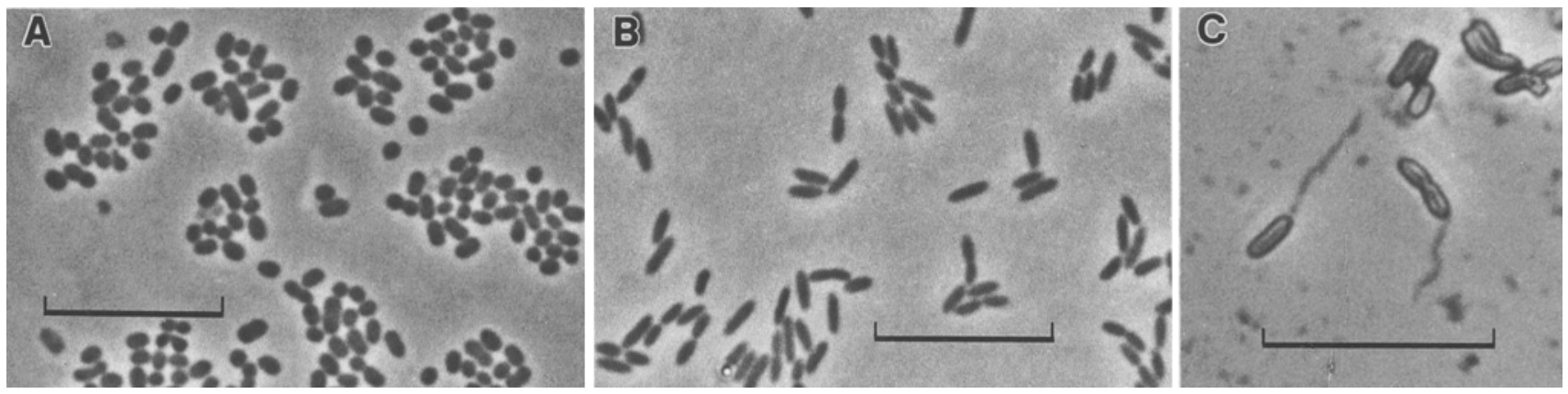

Fig. 2A-C. Phase contrast photomicrographs of strains VonChi2 (A) and GolCh11 (B). Flageila stan of strain GolChi1 (C). Bar equals $10 \mu \mathrm{m}$ 
Table 2. Compounds tested which did not support growth of strains VenChi2 and $\mathrm{ColChi2}$. Substrate concentrations were 5 of $10 \mathrm{mM}$ (2 or $5 \mathrm{mM}$ for aromatic compounds)

D-Glucose, D-fructose, D-xylose, D-ribose, D-cellobiose, D-lactose, D-erythrose, D-manmitol, meso-erythritol, glycerol

Citrate, pyruvate, L-lactate, DL-malate, fumarate, L-tartrate. sorbate (4 mM), glycolate, ethanol

L-Threonine, L-aspartate, L-glycine, L-alanine

Crotonate, 2-hydroxybutyrate, 3-hydroxybutyrate, 4-hydroxybutyrate, 2-oxobulyrate

Protocatechuate, trimethoxycinnamate, resorcinol, 3,4,5-trimethoxybenzcate, phloroglucinol, gallate

Eitectron acceptors (10 mM): Nitrate, sulfate, thiosulfate, sulfur, ferric iron $\left(\mathrm{Fc}^{3+}\right)$

Yeast extract up to $0.2 \%(\mathrm{w} / \mathrm{v})$ had no influence on yicld or rate of growth on quinic acid. Higher concentrations were increasingly inhibitory. Neither strain showed significant growth with yeast extract alone.

Figure 3 shows typical growth curves of both strains on quinic or shikimic acid. Growth rates were almost identical on both substrates $\left(t_{\mathrm{d}}=1.85 \mathrm{~h} ; \mu=0.375 \mathrm{~h}^{-1}\right.$ for strain VenChi2; $t_{\mathrm{d}}=2.65 \mathrm{~h} ; \mu=0.22 \mathrm{~h}^{-1}$ for strain GolChi3). If precultivated on the respective substrates, lag phases were short (1-2 h). However, quinate-grown precultures exhibited a lag phase of $10-12 \mathrm{~h}$ if transferred to medium with shikimate as substrate.

\section{Fermentation balance}

Table 3 shows electron and carbon balances of quinic and shikimic acid fermentation by strains VenChi2 and GolChil. The strains differed with respect to the fermentation products. While strain VenChi2 formed butyrate, acetate, and small amounts of propionate and $\mathrm{H}_{2}$, strain GolChil formed only acetate and propionate. Since $\mathrm{CO}_{2}$ was not quantitated, only the electrons and not the carbon in substrate and products are balanced with strain VenChi2. With strain GolChil, the substrate carbon atoms were completely recovered in the fermentation products indicating that there was not net $\mathrm{CO}_{2}$ formation.

With both strains, growth yields on quinate were linearly dependent on the substrate concentration up to $10 \mathrm{mM}$ quinic acid; at higher concentrations, the medium $\mathrm{pH}$ was shifted beyond the $\mathrm{pH}$ optimum of the culture.

\section{Enzyme actitities}

Table 4 lists the enzyme activities detected in crude extracts of strain VenChi2. Quinate and shikimate were both oxidized with $\mathrm{NAD}^{+}$; activity with $\mathrm{NADP}^{+}$and

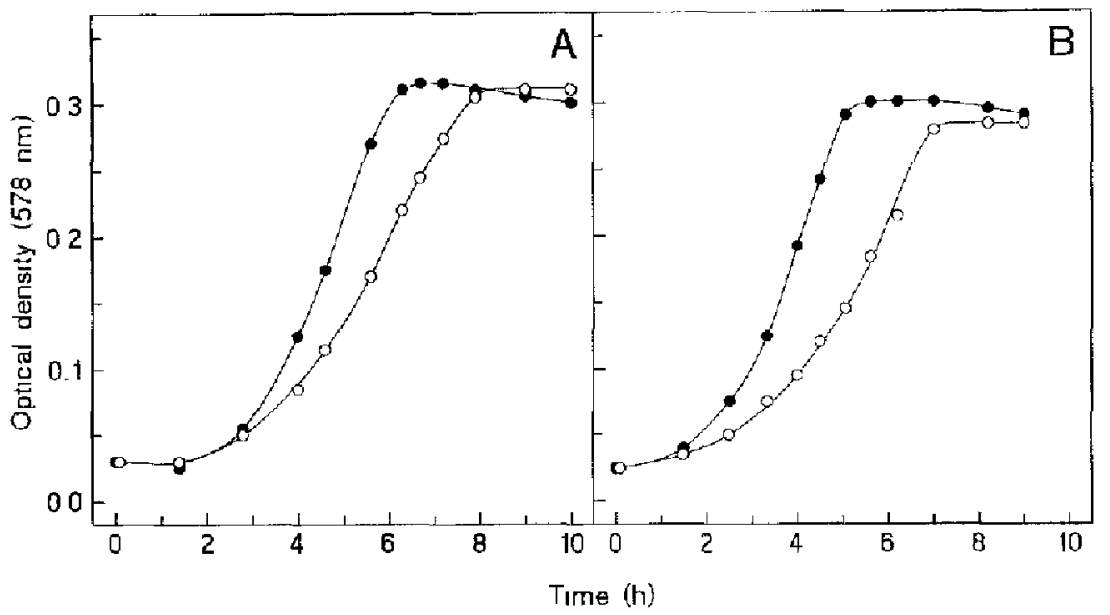

Fig. 3. Growth curves of strains VenCh12 (and GolChil (C) on quinic (A) and shikimic acid (B), $5 \mathrm{mM}$ each

Table 3. Carbon and electron balance and growth yelds of quinic and shikimic acid fermentation by strains VenChi2 and GolChil

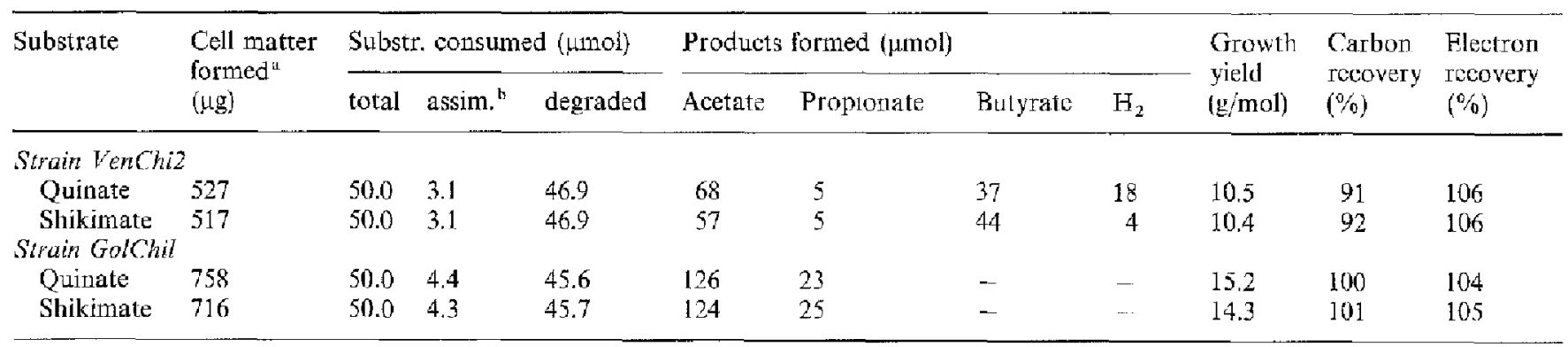

a Calculated from increase in optical density using the experimentally determined coefficients of 198 and $290 \mathrm{mg}$ cell dry matter per 1 of a quinate-grown suspension at $\mathrm{OD}_{578}=1$ for strains VenChi2 and GolChil, respectively b Assimilated substrate was calculated using the equation $17 \mathrm{C}_{7} \mathrm{H}_{12} \mathrm{O}_{6} \rightarrow 28\left\langle\mathrm{C}_{4} \mathrm{H}_{7} \mathrm{O}_{3}\right\rangle+7 \mathrm{CO}_{2}+4 \mathrm{H}_{2} \mathrm{O}$ for quinate; i.e. 5.9 funol quinate were assimilated info $1 \mathrm{mg}$ dry cell matter 
"dye-linked" activities were $<2 \%$ of the $\mathrm{NAD}^{+}$-dependent activity. No aromatic intermediates such as protocatechuic acid or catechol were detected by HPLC in the hydroaromatic dehydrogenase assays. In addition, neither protocatechuate 3,4-dioxygenase nor catechol 1,2dioxygenase activity was detectable in cell extracts.

Pyruvate and 2-oxobutyrate were both oxidatively decarboxylated with $\mathrm{BV}$ as electron acceptor indicating the presence of ferredoxin-coupled pyruvate and 2-oxobutyrate synthases. Propionyl-CoA:acetate and butyrylCoA : acetate $\mathrm{CoA}$ transferase activities were present, as well as all enzyme activities necessary for butyrate and acetate formation from crotonyl-CoA (Table 4).

Most enzyme activities measured with strain VenChi2 were more than sufficient to support the specific in vivo acitivity of quinate fermentation, which was calculated to be $1.2 \mu \mathrm{mol} \cdot \mathrm{min}^{-1} \cdot \mathrm{mg}$ protein ${ }^{-1}$. For strain GolChil, the activity was $0.57 \mu \mathrm{mol} \cdot \mathrm{min}^{-1} \cdot \mathrm{mg}$ protein $^{-1}$. Comparable specific activities though were found only for hydroaromatic dehydrogenases and phosphotransacetylase. Dye-linked pyruvate and 2-oxobutyrate oxidoreductase, the enzymes of acetate formation from crotonyl-CoA, and viologen-dependent carbon monoxide dehydrogenase, however, were found only at very low levels $\left(20-50 \mathrm{nmol} \cdot \mathrm{min}^{-1} \cdot \mathrm{mg}\right.$ protein $\left.{ }^{-1}\right)$. No bydrogenase activity was detected.

\section{Discussion}

\section{Physiology and biochenistry}

The isolated stains arc highly specialized strictly fermentative bacteria thriving only on quinic or shikimic acid as sole source of carbon and energy. They are unable to grow on aromatic compounds or on any other organic compound tested, and employ a hitherto unknown pathway for fermentative breakdown of hydroaromatic compounds which is entirely different from the hydroaromatic pathway present in many aerobic bacteria and rungi.

The initial reactions in fermentative hydroaromatic degradation were identical with those found in the aerobic hydroaromatic pathway (Fig. 4). Specificity of the hydroaromatic dehydrogenases for $\mathrm{NAD}^{+}$is a rather unusual feature among prokaryotes, which have mostly "dye-linked" dehydrogenases that were recently shown to be membrane-associated pyrroloquinoline quinonecoupled enzymes (van Kleef and Duine 1988). Exceptions are the dehydrogenase in Lactobacillus plantarum (Whiting and Coggins 1974) and Rhodococcus rhodochrows (Bruce and Cain 1990), which are NAD ${ }^{+}$linked.

Dehydroshikimate dehydratase, however, the enzyme responsible for aromatization to protocatechuate in the hydroaromatic pathway, was not detected in our strains, and no aromatic intermediates were formed in the hydroaromatic dehydrogenase assays. Rapid growth in the absence of molecular oxygen, and absence of protocatechuate and catechol dioxygenase, both key cnzymes for the respective branch of the 3-oxoadipate pathway, support the conclusion that no aromatization of hydroaromatic to aromatic compounds occurs. In addition, the existing data on anderobic protocatechuate or catechof degradation in enrichment cultures all indicate that such a process is extremely slow and thus highly unlikely to underly the rapid metabolism of hydroaromatics by our strains.

Reversal of the aldol condensations occurring in shikimate biosynthesis, leading to a $\mathrm{C}_{3}$-and a $\mathrm{C}_{4}$-product, is more probable. Depending on the particular cleavage sites, successive aldoytic and/or hydrolytic cleavages would yield e.g. pyruvate and 2,3-dihydroxybutyrate. Unfortunately, the latter is not commercially available, and neither erythrose (erythrose-4-phosphate is the bio-
Table 4. Tnzyme activities in cell extracts of quinate-grown strain VenChi2

\begin{tabular}{|c|c|}
\hline Enzyme & $\begin{array}{l}\text { Specific activity } \\
{\left[\mu \mathrm{mol} \cdot \mathrm{min}^{-1} \cdot \mathrm{mg}^{-1}\right.} \\
\text { prote1n] }\end{array}$ \\
\hline $\begin{array}{l}\text { Quinate dehydrogenase }\left(\mathrm{NAD}^{+}\right) \\
\text {Shikimate dehydrogenase }\left(\mathrm{NAD}^{+}\right)\end{array}$ & $\begin{array}{l}17.6 \\
28.6\end{array}$ \\
\hline $\begin{array}{l}\text { Pyruvate synthase (BV) } \\
\text { 2-Oxobutyrate synthase (BV) } \\
\text { Propionyl-CoA : acetate CoA transferase }\end{array}$ & $\begin{array}{l}1.61 \\
0.42 \\
0.303\end{array}$ \\
\hline $\begin{array}{l}\text { Butyryl-CoA dehydrogenase (NADH) } \\
\text { Butyryl-CoA : acetate CoA transferase }\end{array}$ & $\begin{array}{l}3.54 \\
0.500\end{array}$ \\
\hline $\begin{array}{l}\text { 3-Hydroxybutyryl-CoA dehydratase (HPLC) } \\
\text { (pholometic) }\end{array}$ & $\begin{array}{l}2.86 \\
1.69\end{array}$ \\
\hline $\begin{array}{l}\text { 3-Hydroxybutyryi-CoA dehydrogenase }\left(\mathrm{NAD}^{-}\right) \\
\text {Acetoacetyl-CoA thiolase } \\
\text { Phosphotransacetylase } \\
\text { Acetate kinase }\end{array}$ & $\begin{array}{r}3.66 \\
1.31 \\
14.9 \\
16.0\end{array}$ \\
\hline $\begin{array}{l}\text { Hydrogenase }(\mathrm{BV}) \\
\mathrm{CO} \text { dehydrogenase }\end{array}$ & n.d.a \\
\hline
\end{tabular}

not detectable 
<smiles>[2H]C1(C(=O)O)CC(O)C(O)C(O)C1</smiles><smiles>O=C(O)C1=CC(O)C(O)C(O)C1</smiles><smiles>CC(C)C(C)CNP</smiles><smiles>CC(C)CNNO</smiles><smiles>CC1CC(O)(C(=O)O)CC(=O)C1O</smiles><smiles>CC1CC1CO</smiles><smiles>O=C(O)C1=CC(=O)C(O)C(O)C1</smiles><smiles>CC(C)(C)CO</smiles><smiles>O=C(O)c1ccc(O)c(O)c1</smiles>

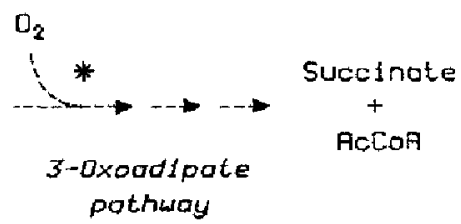

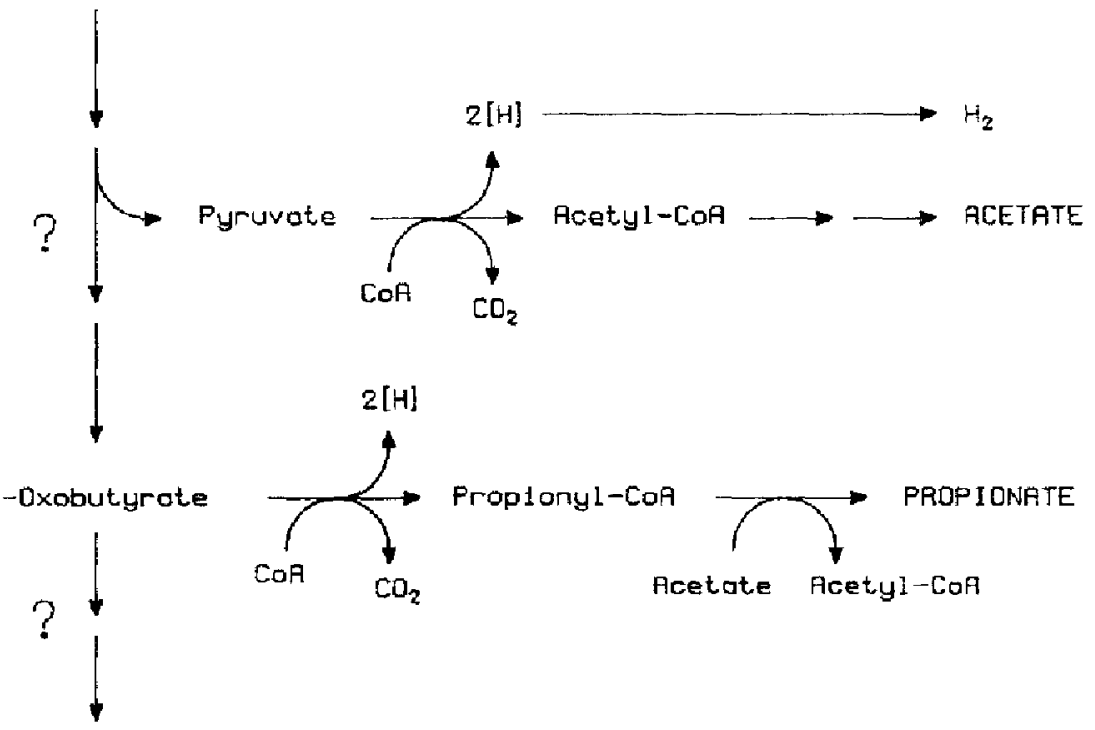

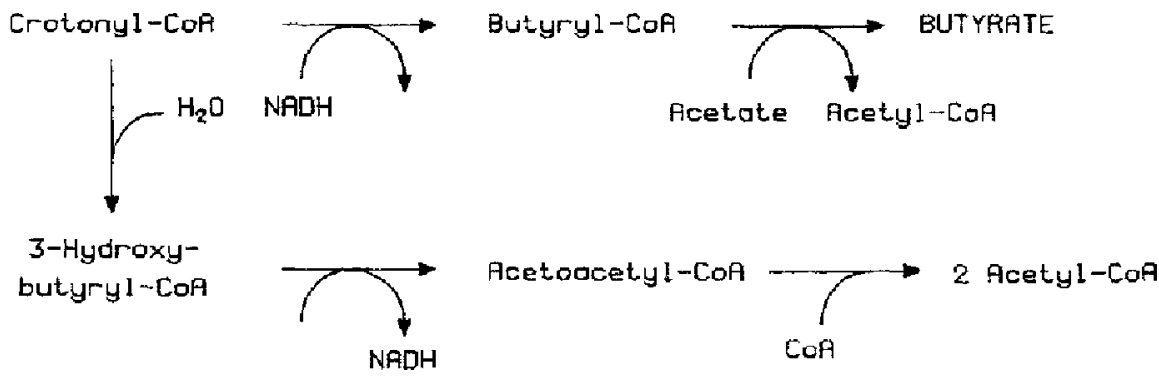

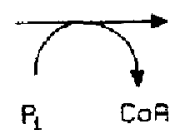

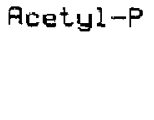

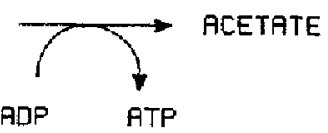

Fig. 4. Pathway proposed for fermentative degrakation of hy droaromatic compounds by strain VenChi2. (?) matks reactions not yet understood, (") are key enzymes of the aerobic hydroaromalic pathway not present in the fermentative strains

synthetic precursor of hydroaromatics in the shikimate pathway) nor 2-oxobutyrate, both isoelectronic with 2,3-dihydroxybutyrate, was a growth substrate for either strain.

Strains VenChi2 and GolChi1 differ with respect to the fate of the aliphatic cleavage products. The fermentation balances of strain VenChi2 with quinate and shikimate (Table 3) agree with the following equation for quinic acid:
$10 \mathrm{C}_{7} \mathrm{H}_{11} \mathrm{O}_{6}+4 \mathrm{H}_{2} \mathrm{O} \rightarrow$ $12 \mathrm{CH}_{3} \mathrm{COO}^{-}+\mathrm{CH}_{3} \mathrm{CH}_{2} \mathrm{COO}$

$+8 \mathrm{CH}_{3}\left(\mathrm{CH}_{2}\right)_{2} \mathrm{COO}^{-}+11 \mathrm{H}^{+}+11 \mathrm{CO}_{2}+5 \mathrm{H}_{2}$ The products are typical of butyric acid fermentation. Propionate was always found as a minor by-product. It is probably not formed through classical propionic acid fermentation, but by oxidative decarboxylation von 2oxobutyrate (Fig. 4). Cell extracts of strain VenChi2 
possessed a viologen-dependent 2-oxobutyrate synthase (Buchanan 1969) at considerable activities (Table 4). Propionate was formed in a similar manner by suspensions of lactate-grown Clostridium homopropionicum cells incubated with 2-hydroxybutyrate (Dörner and Schink 1990).

2-Oxobutyrate could be the product of 2,3-dihydroxybutyrate dehydratase, a reaction resembling tartrate dehydratase (EC 4.2.1.32), dihydroxyacid dehydratase (EC 4.2.1.9), or 3-dehydroquinate dehydratase (EC 4.2.1.10). After reduction to 2-hydroxybutyrate, crotonyl-CoA could be formed by CoA activation and $\alpha$-elimination of water, a sequence analogous to the acrylyl-CoA pathway of propionate fermentation (Wallhöfer and Baldwin 1967). All enzymes necessary to convert crotonyl-CoA to acetate and butyrate were present at high activities (Fig. 4; Table 4).

The fermentation balance of stain GolChil with quinate and shikimate (Table 3 ) indicates that in this case hydroaromatics are fermented without significant formation of $\mathrm{CO}_{2}$ :

$10 \mathrm{C}_{7} \mathrm{H}_{11} \mathrm{O}_{6}^{-}+7.2 \mathrm{H}_{2} \mathrm{O} \rightarrow$

$25.4 \mathrm{CH}_{3} \mathrm{COO}^{-}+5.5 \mathrm{CH}_{3} \mathrm{CH}_{2} \mathrm{COO}^{-}+20.9 \mathrm{H}^{+}$

$+2.7 \mathrm{CO}_{2}$

Two explanations are possible: Either no decarboxylation is involved in the pathway, or strain GolChil possesses a homoacetogenic type of metabolism reassimilating $\mathrm{CO}_{2}$ with the electrons released in the oxidative steps. However, carbon monoxide dehydrogenase activity was detected only at very low levels.

Fermentative degradation of hydroaromatic compounds represents no energetical problem. Quinate and shikimate are at the same redox level as sugars, and comparable ATP yields would be expected. However, the respective growth yields obtained indicate that both strains do not form more than 1-2 ATP per substrate (Stouthamer 1979). Further studics on the metabolic pathways are necessary to clarify these points.

\section{Taxonomy}

Both isolates are gram-negative, non-sporeforming bacteria with a fermentative metabolism. They share the so far unique ability to fermentatively degrade hydroaromatic compounds, and are specialized on these substrates only. However, they differ considerably with respect to many morphological, cytological, and physiological traits.

To date there are no other bacteria known that fermentatively degrade hydroaromatic compounds. This reaction appears to represent the only metabolic activity common to both isolates. Both strains are anaerobic bacteria sensu stricto, i.e. they do not employ oxygen as clectron acceptor; however, strain GolChil proved to be microaerotolerant, superoxide dismutase was positive with this strain. Considering that no easy affiliation with existing genera of anaerobic bacteria (Krieg and Holt 1984) is possible, both strains have to be established as new species as soon as data on their relation to other genera on the basis of rRNA analysis are available.

Strains VenChi2 and GolChil were deposited with the Deutsche Sammlung von Mikroorganismen, Braunschweig, under the numbers DSM 6831 and DSM 6832, respcetively.

Acknowledgements. We are indebted to Prof. Dr. $\mathrm{F}$. Mayer, Göttingen, for preparing electron micrographs of both strains. Special thanks are due to Christine Wondrak for assistance with the experiments, and to Waltraud Dilling and Dr. K. D. Tahoke, DSM, Braunschweig, for determining the DNA base ratios.

\section{References}

Bartholomew (1962) Variables inlluencing results, and the precise definition of steps in gram staining as a means of standardizing the results obtained. Stain Technol 37: 139-165

Beri RK, Grant S, Roberts CF, Smith M, Hawkins AR (1990) Selective overexpression of the QUTE gene encoding catabolic 3-dehydroquinase in nulticopy transfotmants of Aspergillus nidulcins. Biochem .I 265: 337-342

Blenden DC, Goldberg HS (1965) Silver impregnation stain for Leptospira and lisgella. I Bactcriol 89:899-900

Boudet A (1973) Quinic and shikimic acids in woody angiosperms. Phytochemistry 12: $363-370$

Bradford MM (1976) A rapid and sensitive method for the quantitation of microgram quantities of protein utilizing the principle of protein-dye binding. Anal Biochem $72: 248-254$

Brewster D, Jones R, Parke D (1978) The metabolism of shikimate in the rat. Biochem J 170: 257-264.

Bruce NC, Cain RB (1990) Hydroaromatic metabolism in Rhodococcus thodochrous: purification and characterisation of its NAD-dependent quinate dehydrogenase. Arch Microbiol 154: $179-186$

Brune A, Schink B (1990a) Pyrogallol-to-phloroglucinol conversion and other hydroxyl-transfer reactions catalyzed by cell extracts of Pelobacter acidirallisi. J Bacteriol 172: 1070-1076

Brune A, Schink B (1990b) A complete citric acid cycle in assimulatory metabolism of Pelobacter acidigallici, a strictly anaerobic, fermenting bacterium. Arch Microbiol 154: 394-399

Brune A, Schink B (1991) Phloroglucinol pathway in the strictly anaerobic Peiobacter acidigallici: fermentation of trihydroxybenzenes to acetate via triacetic acid. $\Lambda$ rch Microbiol (in press)

Buchanan BB (1969) Role of ferredoxin in the synthesis of $\alpha$-ketobutyrate from propionyl coenzyme $\mathrm{A}$ and carbon dioxide by enzymes from photosynthetic and nonphotosynthetic bacteria. I Biol Chem 244: 4218-4223

Canovas J, Wheelis ML, Stanier RY (1968) Regulation of the enzymes of the $\beta$-ketoadipate pathway in Moraxella calcoaceti$c a .2$. The role of protocatechuate as inducer. Eur J Biochem 3: $293-304$

Cashion P, Holder-Franklin MA, McCully J and Franklin M (1977) A rapid method for base ratio determination of bacterial DNA. Anal Biochem 81: 461-466

Cord-Ruwisch R (1985) A quick method for the determination of dissolved and precipitated sulfides in cultures of sulfate-reducing bacteria. J Microbiol Methods 4: 33-36

Dickert GR. Thduer RK (1978) Carbon monooxide oxidation by Clostriditum thernoace ticum and Clostridium formicoaceticum. J Bacteriol 136: 597-606

Dörner C. Schink B (1990) Clastridium homopropionicum sp, nov., a new strict anacrobc growing with 2-, 3-, or 4-hydroxybutyrate. Arch Microbiol 154: 342-348

Elstner EF, Youngman RJ, OHwald W (1985) Superoxide dismutase. In: Bergmeyer HU (ed) Methods in enzymatic analysis, 3rd edn., vol III. Verlag Chemie, Weinheim, pp 293-302 
Geever RF, Huiet L, Baum JA, Tyler BM, Patcl VB, Rutledge BJ, Case ME, Giles NH (1989) DNA sequence, organization and regulation of the ga gene cluster of Neurospora crassa. $\mathrm{J} \mathrm{Mol}$ Biol 207: 15-34

Gregersen T (1978) Rapid method for distinction of gram-negative from gram-positıve bacteria. Eur J Appl Microbiol Biotechnol 5: $123-1.27$

Grund E, Knorr C, Eichenlaub R (1990) Catabolisn of benzoate and monohydroxylated benzoates by Amvcolatopsis and Sirepfompces spp. Appl Environ Microbiol 56: 1459-1464

Hayaishi $O$, Katagiri M, Rothberg S (1957) Studies on oxygonases: pyroestechase. I Biol Chem 229: $905-920$

Herbert RB (1981) The biosynthesis of secondary metabolites. Chapman \& Hall, London New York.

Ingledew WM, Tai CC (1972) Qumate metabolism in Pseudomonas aerugmosa. Can J Microbiol 18: 1817-1824

Ingledew WM, Tresguerres MEF, Cánova.s. JL (1971) Regulation of the enzymes of the hydroaromatic pathway in Acmetobucter calcoaceticus. J Gen Microbiol 68; 273-282

Krieg NR, Holt IG (cos) (1984) Rergey's manual of systematic bacteriology, vol 1. Williams \& Wilkins, Ballimore, Md., USA

Martin $\Lambda \mathrm{K}$ (1982) The origin of urinary aromatic compounds excreted by ruminants. 1. Metabolism of quinic acid, cyclohexanecarboxylic acid, and non-phenolic aromatic acids to benzoic acid. Br J Nutr 47: 139-154

Matthies C, Mayer F, Schink B (1989) Fermentative degradation of putrescine by new strictly anaerobic bacteria. Arch Microbiol 151: $498-505$

Mesbah M. Premachandran U and Whitman W (1989) Procise measurement of the $G+$ C content of deoxyribonucleic acid by high performance liquid chromalography. Int J Syst Bacteriol 39: $159-167$

Minamikawa $T$ (1976) A comparative sudy on the metabolism of quinic acid and shikimic acid in plants. Bot Mag Tokyo 89: $14 !-1.44$

Möller B, I lerrmantn K (1983) Quinic acid esters of hydroxycinnamic acids in stone and pome fruit. Phytochemistry $22: 477-481$

Nishimura H; Nonaka G-I, Nishioka I (1984) Seven quinic acid gallates from Quercus stenophylla. Phytochemistry 23: 2621 $-2623$

Parke D, Otnston LN (1984) Nutritional diversity of Rhizobiaceae revealed by auxanography. J Gen Microbiol 130: 1743-1750

Pfennig $N$, Wagener $S$ (1986) An improved method of preparing wet mounts for photomicrographs of microorganisms. J Microbiol Methods 4: 303-306

Platen H, Schink B (1987) Mcthanogenic degradation of acetone by an enrichment culture. Arch Microbiol 149: 136 141

Platen H, Schink B (1989) Anaerobic degradation of acetone and higher ketones via carboxylation by newly isolated denitrifying bacteria. J Gen Microbiol 135: 883-891
Platen H, Temmes A, Schink B (1990) Anaerobic degradation of acetone by Desulfococous biacuius spec. now.. Arch Microbiol 154: $355-361$

Procházková L (1959) Bestimmung der Nitrate im Wasser. Z Anal Chem 167: 254-260

Schnell S, Brune A, Schink B (1991) Degradation of hydroxyhydroquinone by the strictly anacrobic fementing bacterium Pelobactemassiliensis sp. nov.. Arch Microbiol 155: 511-516

Smibert AM, Krieg NR (1981) General characterization. In: Gerhardt P (ed) Manual of methods for general bacteriology. American Suciety for Microbiology, Washington DC, pp $409-443$

Staniet RY, Ingraham JL (1954) Protocatechuic acid oxidase. I Biol Chem 210: 799-808

Stoeckigt J, Zenk MH (1974) Enzymic synihesis of chlorogetiic acid from calfeoyl coenzyme $A$ and quinic acid. FEBS Lett 42 : $131-134$

Stouthamer AH (1979) The search for correlation between theoretical and experimental growth yields. In: Quayle JR (ed) Microbial biochemistry, vol 21. University Park Press, Baltimore, pp $1-47$

Tamoaka I and Komagate K (1984) Determination of DNA base composition by reversed-phase high-performance liquid chromatography. FEMS Microbiol Lett 25: 125-128

van Kleef MAG, Duine JA (1988) Bacterial NAD(P)-independent quinate dehydrogenase is a quinoprotcin. Arch Microbiol 150: $32-36$

Wallhöfer P, Baldwin RL (1967) Pathway of propionate fermentation in Bacteroides ruminicola. J Bacteriol 93: 504-505

Whccler LA, Halula M, DeMeo M, Sutter VL, Finegold SM (1979) Metabohsm of shikimic, quizic, cyclohexanecarboxylic acids in germfree, conventional, and gnotobiotic rats. Curr Microbiol 2: 8590

Whit1ng GC, Coggins RA (1971) The role of quinate and shikimate in the metabolism of lactobacilli. Antonie van Leeuwenhock J Microbiol Serol 37: 33-49

Whiting GC, Coggins RA (1974) A new nicotinamide-adenine dinucleotide-dependent hydroaromatic dehydrogenase of Lactobacillus plantarum and its rote in formation of (-3t-3, t-4 dibydroxycyclohexane- $c$-1-carboxylate. Biochem J 141:35-42

Widdel $F$, Pfennig $N$ (1981) Studies on dissimilatory sulfatereducing bacteria that decompose fatty acids I. Isolation of a new sulfatereducer entiched with acetate from saline environments. Description of Desulfobacter postgalei gen. nov. sp. nov. Arch Microbiol 129: 395-400

Widdel F and Pfennig N (1984) Dissimilatory sulfate- or sulfurreducing bacteria. In: Krieg NR, Holt JG (eds) Bergey's manual of systematic bacteriology, vol 1. Willians \& Wilkins, Baltimore. Md, pp 663-579

Yoshida S, Tazaki K, Minamikawa T (1975) Occurrence of shikimic and quinic acids in angiosperns. Phytochemistry 14: 195197 